Marquette University

e-Publications@Marquette

Biomedical Sciences Faculty Research and

Publications

Biomedical Sciences, Department of

$3-1-2016$

Antagonism of GABA-B but not GABA-A receptors in the VTA prevents stress- and intraVTA CRF-induced reinstatement of extinguished cocaine seeking in rats

Jordan M. Blacktop

Marquette University, jordan.blacktop@marquette.edu

Oliver Vranjkovic

Marquette University

Matthieu Mayer

Marquette University

Matthew Van Hoof

Marquette University

David A. Baker

Marquette University, david.baker@marquette.edu

See next page for additional authors

Accepted version. Neuropharmacology, Vol. 102 (March 2016): 197-206. DOI. (C) 2016 Elsevier Ltd. Used with permission. 
Authors

Jordan M. Blacktop, Oliver Vranjkovic, Matthieu Mayer, Matthew Van Hoof, David A. Baker, and John R. Mantsch 


\title{
Antagonism of GABA-B but Not GABA-A Receptors in The VTA Prevents Stress- And Intra-VTA CRF-Induced Reinstatement of Extinguished Cocaine Seeking in Rats
}

\author{
Jordan M. Blacktop \\ Department of Biomedical Sciences, Marquette University, \\ Milwaukee, WI \\ Oliver Vranjkovic \\ Department of Biomedical Sciences, Marquette University, \\ Milwaukee, WI \\ Matthieu Mayer \\ Department of Biomedical Sciences, Marquette University, \\ Milwaukee, WI \\ Matthew Van Hoof \\ Department of Biomedical Sciences, Marquette University, \\ Milwaukee, WI
}


NOT THE PUBLISHED VERSION; this is the author's final, peer-reviewed manuscript. The published version may be accessed by following the link in the citation at the bottom of the page.

\author{
David A. Baker \\ Department of Biomedical Sciences, Marquette University, \\ Milwaukee, WI \\ John R. Mantsch \\ Department of Biomedical Sciences, Marquette University, \\ Milwaukee, WI
}

\begin{abstract}
Stress-induced reinstatement of cocaine seeking requires corticotropin releasing factor (CRF) actions in the ventral tegmental area (VTA). However the mechanisms through which CRF regulates VTA function to promote cocaine use are not fully understood. Here we examined the role of GABAergic neurotransmission in the VTA mediated by GABA-A or GABA-B receptors in the reinstatement of extinguished cocaine seeking by a stressor, uncontrollable intermittent footshock, or bilateral intra-VTA administration of CRF. Rats underwent repeated daily cocaine self-administration $(1.0 \mathrm{mg} / \mathrm{kg} / \mathrm{ing} ; 14 \times 6 \mathrm{~h} /$ day $)$ and extinction and were tested for reinstatement in response to footshock $\left(0.5 \mathrm{~mA}, 0.5^{\prime \prime}\right.$ duration, average every $40 \mathrm{~s}$; range 10-70 s) or intra-VTA CRF delivery (500 ng/side) following intraVTA pretreatment with the GABA-A antagonist, bicuculline, the GABA-B antagonist, 2 -hydroxysaclofen or vehicle. Intra-VTA bicuculline (1, 10 or $20 \mathrm{ng} / \mathrm{side}$ ) failed to block footshock- or CRF-induced cocaine seeking at either dose tested. By contrast, 2 -hydroxysaclofen $(0.2$ or $2 \mu \mathrm{g} / \mathrm{side})$ prevented reinstatement by both footshock and intra-VTA CRF at a concentration that failed to attenuate food-reinforced lever pressing ( $45 \mathrm{mg}$ sucrose-sweetened pellets; FR4 schedule) in a separate group of rats. These data suggest that GABA-B receptor-dependent CRF actions in the VTA mediate stress-induced cocaine seeking and that GABA-B receptor antagonists may have utility for the management of stress-induced relapse in cocaine addicts.
\end{abstract}

Keywords: Stress; Relapse; Reinstatement; GABA-B receptors; Ventral tegmental area; Cocaine

\title{
1. Introduction
}

Understanding the mechanisms that contribute to relapse to drug use in cocaine addicts is critical for the development of new and

Neuropharmacology, Vol 102 (March 2016): pg. 197-206. DOI. This article is @ Elsevier and permission has been granted for this version to appear in e-Publications@Marquette. Elsevier does not grant permission for this article to be further copied/distributed or hosted elsewhere without the express permission from Elsevier. 
more effective treatment approaches for managing addiction. In rats, relapse can be studied using reinstatement models in which the ability of a stimulus to re-establish or reinstate cocaine seeking behavior in rats or mice following extinction is used as an indicator of its likelihood to promote relapse to use in human addicts (Mantsch et al., 2015). Many of the same stimuli that contribute to drug use in humans (stress, drug-associated cues, drug re-exposure), reinstate cocaine seeking following self-administration (SA) and extinction in rats.

Among the triggers for relapse, stress is particularly problematic due to its unpredictable and often uncontrollable nature. Reports from cocaine users that relapse is frequently related to the onset of stressful life events are supported by laboratory findings demonstrating that personalized scripts that relay stress-related imagery can precipitate craving in cocaine-dependent individuals (Sinha et al., 1999). In rats, it has been reported that a number of stressors can reinstate extinguished cocaine seeking following intravenous self-administration (see Mantsch et al., 2015 for review). However, most studies investigating stress-induced relapse in rats have used electric footshock delivered through the grid floor of the operant conditioning chambers as the reinstating stressor. Notably, we have previously reported that, like stress imagery in human addicts (Fox et al., 2005), the ability of footshock to reinstate cocaine seeking in rats increases according to the amount of prior drug intake (Mantsch et al., 2008).

Several studies have demonstrated that stress-induced reinstatement of cocaine seeking requires corticotropin-releasing factor (CRF) actions in the ventral tegmental area (VTA; Wang et al., 2005, Wang et al., 2007, Blacktop et al., 2011, Chen et al., 2014 and Vranjkovic et al., 2014) and that intra-VTA CRF administration is sufficient to reinstate cocaine seeking following SA and extinction in rats (Wang et al., 2005 and Blacktop et al., 2011). However, the downstream processes in the VTA through which CRF promotes drug use are unclear. Mechanistic studies have focused on CRF regulation of glutamatergic neurotransmission in the VTA (Wise and Morales, 2010). In the VTA, CRF has been reported to increase glutamate release as measured by both in vivo microdialysis ( Wang et al., 2005) and spontaneous EPSCs in slice preparations ( Hahn et al., 2009 and Williams et al., 2014), as well as post-synaptic excitability through increases in AMPA:NMDA receptor ratios ( Ungless

Neuropharmacology, Vol 102 (March 2016): pg. 197-206. DOI. This article is (C Elsevier and permission has been granted for this version to appear in e-Publications@Marquette. Elsevier does not grant permission for this article to be further copied/distributed or hosted elsewhere without the express permission from Elsevier. 
et al., 2003 and Hahn et al., 2009). Moreover, intra-VTA perfusion with kynurenic acid, which has a pharmacological profile that includes AMPA and NMDA receptor antagonism, prevents reinstatement in response to either footshock or intra-VTA CRF (Wang et al., 2005).

However, the actions of stress and CRF in the VTA are complex and appear to also include, under some circumstances, inhibition of neuronal activity (Ungless et al., 2004, Wanat et al., 2013 and Twining et al., 2015) or terminal neurotransmitter release (Williams et al., 2014). The VTA receives dense GABAergic inputs from a number of regions, including the nucleus accumbens (Yim and Mogenson, 1980, Xia et al., 2011 and Bocklisch et al., 2013) and bed nucleus of the stria terminalis (Kudo et al., 2012), both of which have been implicated in stress-induced cocaine seeking in rats (Erb and Stewart, 1999, McFarland et al., 2004 and Vranjkovic et al., 2014). Additionally, the VTA contains GABAergic interneurons that regulate efferent neuronal projections from the region (Steffensen et al., 1998 and Cruz et al., 2004) and dense GABAergic innervation from the rostromedial tegmental nucleus (i.e., tail of the VTA; Jhou et al., 2009, Matsui and Williams, 2011 and Barrot et al., 2012). It has also been reported that CRF promotes GABAergic neurotransmission within the VTA. For example, CRF application to the VTA in ex vivo slice preparations promotes GABA-B regulation of $G$ protein-coupled inwardly-rectifying potassium (GIRK) channels on dopamine cells ( Beckstead et al., 2009). Despite these findings, the effects of GABA receptor antagonism in the VTA on stress-induced reinstatement have not been reported.

In the present study we investigate the potential contribution of $G_{A B A}$ and $G A B A_{B}$ receptors in the VTA to the reinstatement of extinguished cocaine seeking in response to footshock or delivery of CRF into the VTA following self-administration. Rats with a history of daily self-administration that results in robust shock and intra-VTA CRF-induced reinstatement following extinction $(14 \times 6 \mathrm{~h} /$ day; $1 \mathrm{mg} / \mathrm{kg} /$ inf) received intra-VTA injections of the $\mathrm{GABA}_{\mathrm{A}}$ receptor antagonist, bicuculline, or the $\mathrm{GABA}_{B}$ receptor antagonist, 2hydroxysaclofen, prior to reinstatement testing. Notably, in contrast to previous work targeting VTA GABA receptors which used a cocktail of receptor agonists (baclofen/muscimol; McFarland et al., 2004), the present study uses receptor selective antagonists, thereby permitting

Neuropharmacology, Vol 102 (March 2016): pg. 197-206. DOI. This article is @ Elsevier and permission has been granted for this version to appear in e-Publications@Marquette. Elsevier does not grant permission for this article to be further copied/distributed or hosted elsewhere without the express permission from Elsevier. 
1) assessment of the contribution of $G A B A_{A}$ vs. $G A B A_{B}$ receptors and 2 ) the regulation of cocaine seeking through GABAergic signaling that is engaged by CRF and/or during stress.

\section{Methods}

\subsection{Subjects}

Adult male Sprague-Dawley rats (Harlan Laboratories, St. Louis, MO) were housed individually under a $12 \mathrm{~h} / 12 \mathrm{~h}$ reversed light/dark cycle (lights on at 7:00 PM) in a temperature and humidity controlled AAALAC-accredited animal facility. All procedures were approved by the Marquette University IACUC and carried out in accordance with the NIH Guide for the Care and Use of Laboratory Animals.

\subsection{Catheter and cannula implantation}

For the reinstatement studies, rats were implanted with chronic indwelling jugular catheters under ketamine $\mathrm{HCl}(100 \mathrm{mg} / \mathrm{kg}$, ip) and xylazine ( $2 \mathrm{mg} / \mathrm{kg}$, ip) anesthesia and with bilateral $2.1-\mathrm{cm} 23$ gauge guide cannulae aimed at the VTA for intracranial injections as previously described (Blacktop et al., 2011 and Vranjkovic et al., 2014). The tips of the guide cannulae were aimed $0.5 \mathrm{~mm}$ above the target injection site (the posterior VTA) using the following coordinates determined from Paxinos and Watson (2007): $12^{\circ}$ angle away from midline; A/P - $5.6 \mathrm{~mm}$ from bregma; $M / L \pm 2.2 \mathrm{~mm}$ from midline; and $\mathrm{D} / \mathrm{V}-6.7 \mathrm{~mm}$ from the skull surface. Placements for cannula targeting the VTA for rats from each of the experiments are depicted in Fig. 1.

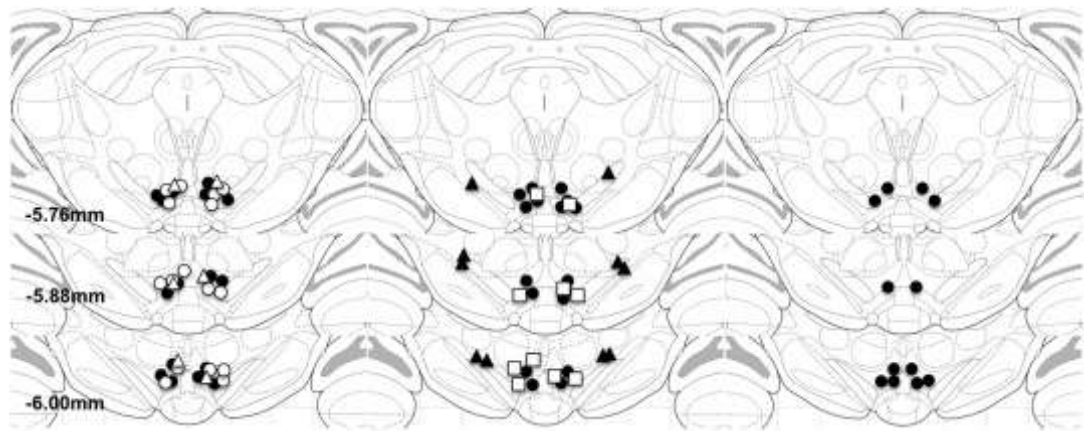

Fig. 1. Intracranial injection sites. Panels represent atlas diagrams (coronal sections $-5.6,-5.8$ and $-6.1 \mathrm{~mm}$ relative to Bregma; Paxinos and Watson, 2007)

Neuropharmacology, Vol 102 (March 2016): pg. 197-206. DOI. This article is (C) Elsevier and permission has been granted for this version to appear in e-Publications@Marquette. Elsevier does not grant permission for this article to be further copied/distributed or hosted elsewhere without the express permission from Elsevier. 
NOT THE PUBLISHED VERSION; this is the author's final, peer-reviewed manuscript. The published version may be accessed by following the link in the citation at the bottom of the page.

depicting injection sites from rats included in experiments in which effects of VTA injections of $1 \mathrm{ng} /$ side (closed circles), $10 \mathrm{ng} /$ side (open circles), or $20 \mathrm{ng} / \mathrm{side}$ (open triangles) bicuculline on CRF- and shock-induced cocaine seeking were tested (left); rats included in experiments in which effects of VTA injections of $0.2 \mu \mathrm{g} / \mathrm{side}$ (closed circles) or $2 \mu \mathrm{g} /$ side (open squares) 2 -hydroxysaclofen on CRF- and shock-induced cocaine seeking were tested and rats with injections outside of the VTA used as anatomical controls (center; closed triangles); and rats included in the experiments testing for effects on food-reinforced lever pressing (right; closed circles).

\subsection{Drugs}

Cocaine $\mathrm{HCl}$ was provided by the National Institute on Drug Abuse through the Drug Supply Program. CRF was purchased from Sigma-Aldrich and was administered at a concentration of $500 \mathrm{ng} / \mathrm{side}$ (Blacktop et al., 2011) dissolved in artificial cerebral spinal fluid (aCSF; $0.25 \mu \mathrm{l} /$ side). The $\mathrm{GABA}_{\mathrm{A}}$ receptor antagonist (-)-bicuculline methiodide was purchased from Tocris Bioscience and was administered at doses of 1,10 and $20 \mathrm{ng} /$ side $(0.002$ and 0.02 and $0.04 \mathrm{nmol} / \mathrm{side})$ dissolved in aCSF $(0.25 \mu \mathrm{l} / \mathrm{side})$. The doses used were selected based on prior reports assessing VTA effects (Sandner et al., 1996, Trojniar and Klejbor, 1999, Laviolette and van der Kooy, 2001, Grubb et al., 2002, Echo et al., 2002 and Lavezzi et al., 2015). The occurrence of seizures prevented testing for effects of higher doses. The $\mathrm{GABA}_{B}$ receptor antagonist 2-hydroxysaclofen was also purchased from Tocris Bioscience and was administered at doses of 0.2 and $2 \mu \mathrm{g} /$ side $(0.75$ and $7.5 \mathrm{nmol} /$ side) dissolved in aCSF $(0.25 \mu \mathrm{l} / \mathrm{side})$. The doses used were also selected based on prior reports assessing VTA effects (Xi and Stein, 1999, Echo et al., 2002, Ackerman et al., 2003 and Miner et al., 2010).

\subsection{Cocaine self-administration/extinction}

After recovery from surgery, rats were trained to self-administer cocaine $(1.0 \mathrm{mg} / \mathrm{kg} / \mathrm{inf}$, iv) by pressing a lever under a fixed ratio 1 schedule during daily $2-h$ sessions, within which the active (i.e., front) lever was extended into the chamber and the corresponding stimulus light was illuminated. Pressing the lever resulted in an iv infusion of cocaine solution ( $200 \mu$ l over $5 \mathrm{~s}$ ) followed by a 25 -s time-out period during which the stimulus light was extinguished but the lever remained extended. Responding on a second, inactive (i.e., back) lever was recorded but had no programmed consequences. Response requirements were gradually increased until rats displayed stable

Neuropharmacology, Vol 102 (March 2016): pg. 197-206. DOI. This article is (C) Elsevier and permission has been granted for this version to appear in e-Publications@Marquette. Elsevier does not grant permission for this article to be further copied/distributed or hosted elsewhere without the express permission from Elsevier. 
responding (within $10 \%$ of the mean over 3 consecutive sessions) under an FR4 schedule at which time they were allowed to selfadminister cocaine six hours daily for 14 consecutive days. We have previously found that robust reinstatement of cocaine seeking in response to either footshock or intra-VTA CRF is only observed when rats are tested after self-administration under these "long-access" conditions (Mantsch et al., 2008 and Blacktop et al., 2011). After the 14-day self-administration test period rats underwent extinction during ten consecutive 2 -h sessions within which the cocaine solution was replaced by saline. As was the case during self-administration, the drug lever stimulus light was illuminated during the extinction session except during the post-infusion "time-out" period. Once rats displayed less than 20 responses/session over two consecutive sessions under extinction conditions, reinstatement testing was initiated.

\subsection{Reinstatement testing}

After extinction, rats were tested for the effects of intra-VTA pretreatment with either bicuculline (GABA $A_{A}$ antagonist) or 2hydroxysaclofen ( $G A B A_{B}$ antagonist) on reinstatement in response to electric footshock or bilateral intra-VTA CRF injections. Separate groups of rats were tested for the effects of $1 \mathrm{ng}, 10$ or $20 \mathrm{ng} / \mathrm{side}$ bicuculline or 0.2 or $2 \mu \mathrm{g} /$ side 2 -hydroxysaclofen. Each rat was tested for reinstatement in response to shock and intra-VTA CRF following intra-VTA vehicle and drug pretreatment (four reinstatement tests total). The two-hour reinstatement sessions were otherwise identical to the extinction sessions (i.e., the drug lever stimulus light was illuminated except during the post-infusion "time-out" period). Consecutive reinstatement sessions were always separated by additional extinction training and rats were required to display less than 20 cocaine lever responses during an intervening extinction session in order to be tested again for reinstatement. The sequence of reinstatement testing (shock and CRF) was counterbalanced across rats such that some rats were tested for effects on shock-induced reinstatement first, while others were tested for CRF-induced reinstatement first. All microinfusions were delivered in a volume of $0.25 \mu \mathrm{l} /$ side over a 1 -min period with an additional 1 -min period to allow for drug diffusion, ten minutes prior to the reinstatement session. In addition to testing for the effects of GABA receptor

Neuropharmacology, Vol 102 (March 2016): pg. 197-206. DOI. This article is (C) Elsevier and permission has been granted for this version to appear in e-Publications@Marquette. Elsevier does not grant permission for this article to be further copied/distributed or hosted elsewhere without the express permission from Elsevier. 
NOT THE PUBLISHED VERSION; this is the author's final, peer-reviewed manuscript. The published version may be accessed by following the link in the citation at the bottom of the page.

antagonists on shock- and CRF-induced cocaine seeking, the effects of intra-VTA administration of bicuculline and 2-hydroxysaclofen in the absence of shock or CRF were assessed in separate groups of rats.

\subsection{Shock-induced reinstatement of cocaine seeking}

To determine the contribution of VTA GABA $A_{A}$ and GABA $B$ receptors to stress-induced cocaine seeking, rats were tested for the ability of electric footshock, delivered though the stainless steel grid floors of the self-administration chambers, to reinstate cocaine seeking following pretreatment with bilateral antagonist drug injections into the VTA ten minutes prior to shock. During the 15-min footshock period, the houselight was illuminated and the levers were retracted and stimulus lights extinguished. Shocks (0.5 mA, 0.5" duration) were delivered an average of every $40 \mathrm{~s}$ (range 10-70 s). Immediately following the shock period, the houselight was extinguished and the active and inactive levers were extended into the chamber and the active lever stimulus light was illuminated (conditions identical to both self-administration and extinction). We have reported that these parameters produce robust footshock-induced reinstatement under the self-administration conditions used (Mantsch et al., 2008). Each rat was tested twice for shock-induced reinstatement in counter-balanced sequence: once following intra-VTA drug delivery and once following intra-VTA vehicle administration.

\subsection{CRF-induced reinstatement of cocaine seeking}

Rats were also tested for reinstatement in response to bilateral intra-VTA injections of CRF. Ten minutes after VTA administration of bicuculline, 2-hydroxysaclofen or vehicle, rats received bilateral injections with CRF (500 ng/side delivered a volume of $0.25 \mu \mathrm{l} / \mathrm{side}$ over a 1-min period ten minutes prior to reinstatement testing). Each rat was tested twice for CRF-induced reinstatement in counterbalanced sequence: once following intra-VTA drug delivery and once following intra-VTA vehicle administration. We have previously reported that this CRF concentration produces robust reinstatement under the self-administration conditions used (Blacktop et al., 2011). Moreover, CRF delivery via cannula placed into regions adjacent to the VTA failed to reinstate cocaine seeking ( $n=5$; extinction responses/2-

Neuropharmacology, Vol 102 (March 2016): pg. 197-206. DOI. This article is (C) Elsevier and permission has been granted for this version to appear in e-Publications@Marquette. Elsevier does not grant permission for this article to be further copied/distributed or hosted elsewhere without the express permission from Elsevier. 
NOT THE PUBLISHED VERSION; this is the author's final, peer-reviewed manuscript. The published version may be accessed by following the link in the citation at the bottom of the page.

h session: $11.2 \pm 1.59$; CRF-induced responses/2-h session: $8.8 \pm 1.39)$.

\subsection{Testing for effects on food-reinforced lever pressing}

In order to confirm that the effects of intra-VTA injections on reinstatement were not attributable to non-specific motor impairment, separate groups of rats were tested for effects on sucrose pelletreinforced lever pressing. These rats were maintained at $90 \%$ of their free-feeding body weights and trained to self-administer $45 \mathrm{mg}$ sucrose-sweetened food pellets (BioServ) by pressing a response lever under a FR4 schedule of reinforcement during 30-min sessions. Once stable response patterns were observed (responding within $10 \%$ of the mean over 3 sessions), rats were tested for the effects of intra-VTA delivery of 2-hydroxysaclofen, as described above, on responding.

\subsection{Histological confirmation of injection sites}

The accuracy of cannula implantation was confirmed postmortem in each rat after cardiac perfusion with $60-\mathrm{ml} \mathrm{NaCl}$ followed by $60-\mathrm{ml} 2.5 \%$ buffered neutral formalin under sodium barbital anesthesia (55 mg/kg). Brains were removed and stored in $2.5 \%$ buffered formalin for at least one day. 200- $\mu \mathrm{m}$ sections were cut using a vibrotome, slide-mounted, and stained with cresyl violet for placement confirmation using a light microscope. Rats with injection sites outside of the VTA were excluded from the primary analysis and combined into a separate "missed placement" group for assessment of anatomical specificity of drug effects on shock-induced cocaine seeking.

\subsection{Statistical analyses}

The effects of each drug/dose combination on CRF and shockinduced reinstatement were analyzed separately using 2-way repeated measure ANOVA with reinstatement (responding during the reinstatement session vs. the preceding extinction session) and intraVTA drug treatment (drug vs. vehicle) as factors. A similar analysis was used to assess effects on food-reinforced responding (2-way

Neuropharmacology, Vol 102 (March 2016): pg. 197-206. DOI. This article is (C) Elsevier and permission has been granted for this version to appear in e-Publications@Marquette. Elsevier does not grant permission for this article to be further copied/distributed or hosted elsewhere without the express permission from Elsevier. 
repeated measures with reinforced lever pressing and drug treatment as factors). Analysis of drug effects alone consisted of comparison with the prior extinction session using paired t-tests. Statistical analyses were conducted using SPSS statistics software. For all analyses, statistical significance was defined as $p<0.05$.

\section{Results}

\subsection{Placements}

The sites of injections for rats tested for the effects of intra-VTA drug injections and for anatomical control rats are depicted in Fig. 1.

\subsection{SA and extinction}

Cocaine self-administration and extinction in rats used for each experiment are shown in Table 1 and were comparable across groups. Moreover, the numbers of sessions required for acquisition of cocaine self-administration, total cocaine intake across all self-administration sessions and the numbers of sessions needed to reach the extinction criteria did not differ across groups (data not shown).

Table 1. Cocaine self-administration and extinction in each group of rats that underwent reinstatement testing. Data represent infusions/6-h session ( \pm S.E.) on days 1 and 14 of self-administration and responses/2-h session $( \pm$ S.E.) during the final extinction session prior to starting reinstatement testing in separate groups of rats tested for effects of intra-VTA bicuculline (1, 10 , or $20 \mathrm{ng} / \mathrm{side}$ ) or 2 -hydroxysaclofen $(0.2$ or $2 \mu \mathrm{g} / \mathrm{side})$ on shock and CRFinduced reinstatement.

\begin{tabular}{|c|c|c|c|}
\hline \multirow{2}{*}{$\begin{array}{c}\text { Intra-VTA pretreatment } \\
\text { group }\end{array}$} & \multicolumn{2}{|c|}{ Infusions/6-h session ( \pm S.E.) } & \multirow{2}{*}{$\begin{array}{c}\text { Responses/2-h session } \\
\text { ( } \pm \text { S.E.) } \\
\text { Last Ext Day }\end{array}$} \\
\hline & SA Day 1 & SA Day 14 & \\
\hline Bicuculline (1 ng/side) & $83.75( \pm 8.66)$ & $92.75( \pm 14.07)$ & $10.38( \pm 1.24)$ \\
\hline Bicuculline (10 ng/side) & $79.00( \pm 7.57)$ & $96.00( \pm 11.48)$ & $14.57( \pm 3.46)$ \\
\hline Bicuculline (20 ng/side) & $61.38( \pm 7.80)$ & $83.00( \pm 17.21)$ & $12.50( \pm 1.76)$ \\
\hline $\begin{array}{l}\text { 2-hydroxysaclofen } \\
(0.2 \mu \mathrm{g} / \text { side })\end{array}$ & $70.80( \pm 3.81)$ & $86.4( \pm 5.56)$ & $10.20( \pm 1.56)$ \\
\hline -hydroxysaclofen ( $2 \mu \mathrm{g} / \mathrm{side})$ & $72.22( \pm 3.27)$ & $82.44( \pm 4.23)$ & $6.22( \pm 1.54)$ \\
\hline
\end{tabular}

Neuropharmacology, Vol 102 (March 2016): pg. 197-206. DOI. This article is @ Elsevier and permission has been granted for this version to appear in e-Publications@Marquette. Elsevier does not grant permission for this article to be further copied/distributed or hosted elsewhere without the express permission from Elsevier. 


\subsection{Intra-VTA injections of 2-hydroxysaclofen or bicuculline do not reinstate cocaine seeking}

Neither intra-VTA 2-hydroxysaclofen nor intra-VTA bicuculline injections induced cocaine-seeking behavior. Cocaine seeking following intra-VTA injections of bicuculline (10 or $20 \mathrm{ng} /$ side; $n=4 /$ dose) or 2 hydroxysaclofen ( 0.2 or $2 \mu \mathrm{g} /$ side; $n=5 /$ dose) is shown in Fig. 2. Separate 2-way ANOVAs failed to show overall increases in responding (i.e., reinstatement) relative to extinction, effects of intra-VTA drug dose or reinstatement $x$ dose interactions.

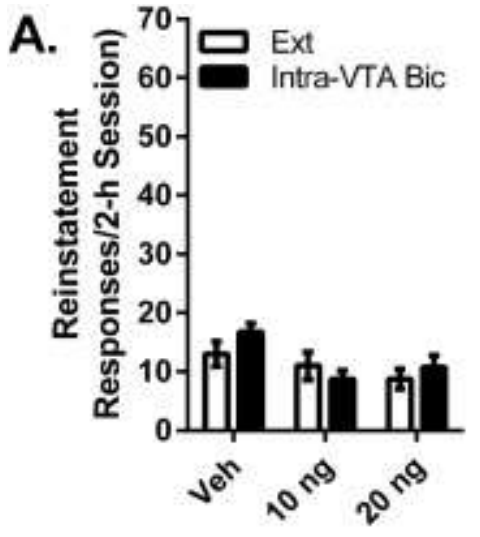

BIC (ng/side)

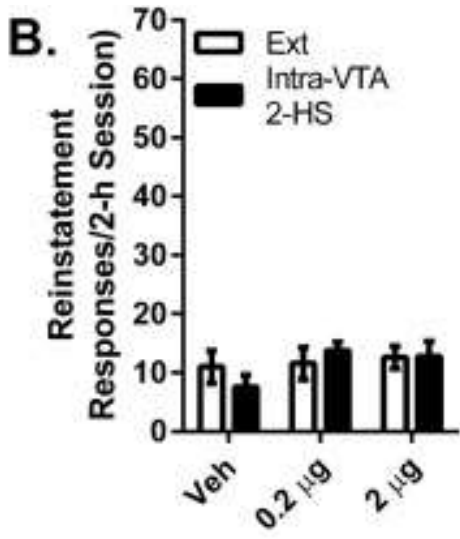

2-HS ( $\mu \mathrm{g} / \mathrm{side})$

Fig. 2. Intra-VTA injections of bicuculline or 2-hydroxysaclofen do not induce cocaine seeking. Data represent responding (lever presses/2-h session \pm S.E.) recorded during reinstatement testing following intra-VTA injections of vehicle and bicuculline (BIC; 10 or $20 \mathrm{ng} /$ side; $\mathrm{A}$ ) or 2 -hydroxysaclofen (2-HS; 0.2 or $2 \mu \mathrm{g} /$ side; $\mathrm{B}$ ) and responding during the corresponding previous extinction (Ext) sessions.

\subsection{Effects of intra-VTA bicuculline injections on shock- and intra-VTA CRF-induced reinstatement}

Antagonism of $\mathrm{GABA}_{A}$ receptors in the VTA failed to alter stressor intra-VTA CRF-induced cocaine seeking. The effects of intra-VTA injections of three bicuculline concentrations ( $1 \mathrm{ng} / \mathrm{side}, 10 \mathrm{ng} / \mathrm{side}$, and $20 \mathrm{ng} /$ side) on shock-induced cocaine seeking were tested and are shown in Fig. 3. Consistent with other reports (e.g., Echo et al., 2002) we were unable to administer higher concentrations due to the emergence of seizures. Separate 2-way repeated measures (reinstatement $\times$ drug treatment) ANOVAs were conducted for each bicuculline dose. In all cases, shock-induced reinstatement was not 
altered by intra-VTA bicuculline. At each bicuculline concentration, significant shock-induced reinstatement was observed $(1 \mathrm{ng} /$ side: $\mathrm{F}_{1,5}=9.967, \mathrm{P}<0.05, \mathrm{n}=6 ; 10 \mathrm{ng} /$ side: $\mathrm{F}_{1,4}=42.631 \mathrm{P}<0.01$, $\mathrm{n}=5 ; 20 \mathrm{ng} /$ side: $\mathrm{F}_{1,3}=33.178 \mathrm{P}=0.01, \mathrm{n}=4$ ). However significant effects of VTA bicuculline administration or significant bicuculline $\times$ reinstatement interactions were not found.
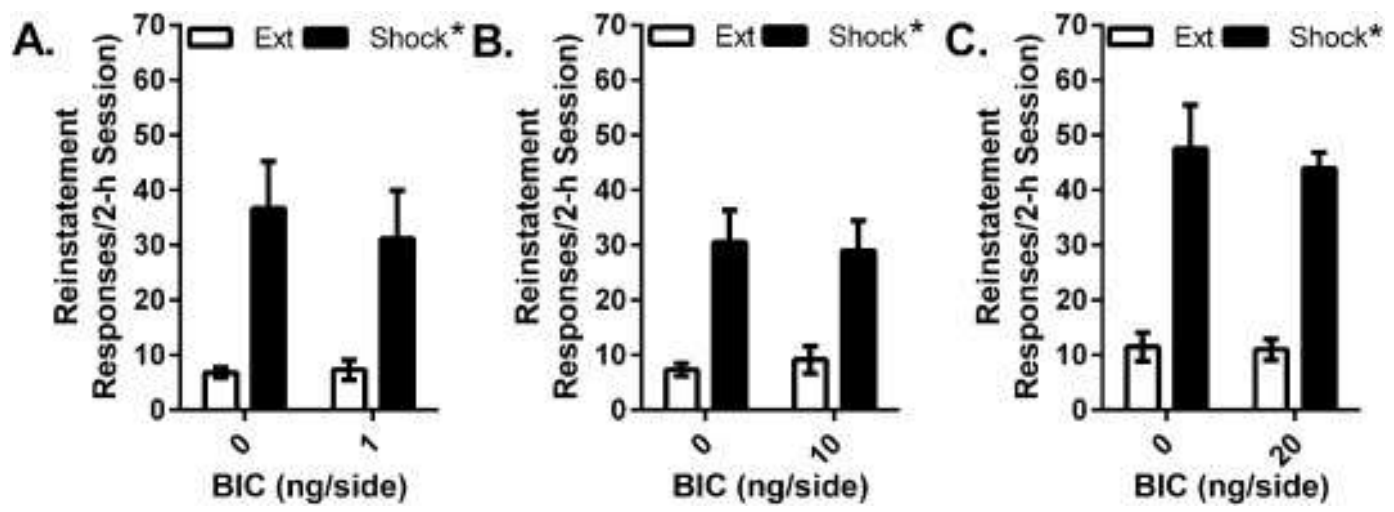

Fig. 3. Effects of intra-VTA bicuculline injections on stress-induced reinstatement. Data represent responding (lever presses/2-h session \pm S.E.) recorded during reinstatement testing following electric footshock $\left(0.5 \mathrm{~mA}, 0.5^{\prime \prime}\right.$ shocks delivered an average of every $40 \mathrm{~s}$ over a 15 -min period) in rats pretreated with intra-VTA injections of vehicle or $1 \mathrm{ng} / \mathrm{side}(\mathrm{A}), 10 \mathrm{ng} / \mathrm{side}(B)$, or $20 \mathrm{ng} / \mathrm{side}(C)$ concentrations of the $\mathrm{GABA}_{\mathrm{A}}$ receptor antagonist, bicuculline (BIC), and responding during the previous extinction (Ext) session. Shock reinstated cocaine seeking regardless of whether rats were pretreated with vehicle or intra-VTA bicuculline ( $* \mathrm{P}<0.05$ overall shock reinstatement effect vs. Ext but no effect of BIC or shock $\times$ BIC interaction).

The effects of intra-VTA injections of the three bicuculline concentrations ( $1 \mathrm{ng} / \mathrm{side}, 10 \mathrm{ng} / \mathrm{side}$, and $20 \mathrm{ng} / \mathrm{side}$ ) on cocaine seeking in response to bilateral intra-VTA CRF injections ( $500 \mathrm{ng} / \mathrm{side}$ ) are shown in Fig. 4. Separate 2-way repeated measures (reinstatement $\times$ drug treatment) ANOVAs were conducted for each bicuculline concentration. As was the case with shock, CRF-induced reinstatement was not altered by intra-VTA bicuculline. At each bicuculline concentration, significant CRF-induced reinstatement was observed $\left(1 \mathrm{ng} /\right.$ side: $\mathrm{F}_{1,5}=35.698, \mathrm{P}=0.001, \mathrm{n}=6 ; 10 \mathrm{ng} / \mathrm{side}$ : $\mathrm{F}_{1,4}=15.896, \mathrm{P}<0.05, \mathrm{n}=5 ; 20 \mathrm{ng} /$ side: $\mathrm{F}_{1,3}=271.75, \mathrm{P}<0.001$, $\mathrm{n}=4$ ). However significant effects of bicuculline administration or significant bicuculline $\times$ reinstatement interactions were not found.

Neuropharmacology, Vol 102 (March 2016): pg. 197-206. DOI. This article is @ Elsevier and permission has been granted for this version to appear in e-Publications@Marquette. Elsevier does not grant permission for this article to be further copied/distributed or hosted elsewhere without the express permission from Elsevier. 

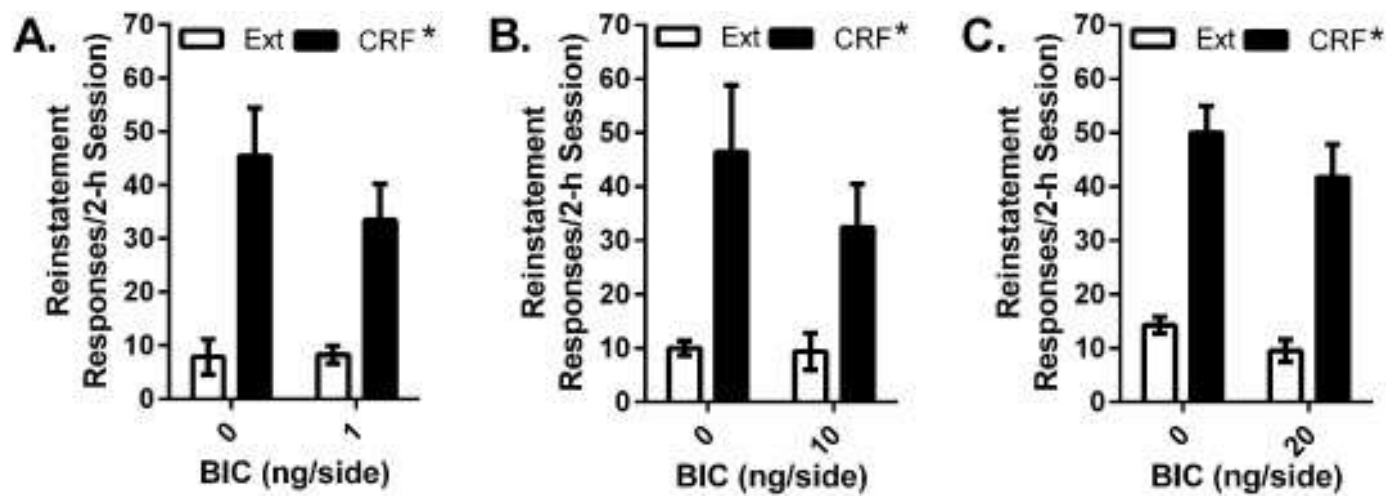

Fig. 4. Effects of intra-VTA bicuculline injections on CRF-induced reinstatement. Data represent responding (lever presses/2-h session \pm S.E.) recorded during reinstatement testing following bilateral intra-VTA administration of CRF (500 ng/side) in rats pretreated with intra-VTA injections of vehicle or $1 \mathrm{ng} / \mathrm{side}(\mathrm{A}), 10 \mathrm{ng} / \mathrm{side}(\mathrm{B})$, or $20 \mathrm{ng} /$ side (C) concentrations of the $\mathrm{GABA}_{\mathrm{A}}$ receptor antagonist, bicuculline (BIC), and responding during the previous extinction (Ext) session. Intra-VTA CRF reinstated cocaine seeking regardless of whether rats were pretreated with vehicle or intra-VTA bicuculline ( $* P<0.05$ overall CRF reinstatement effect vs. Ext but no effect of BIC or CRF $\times$ BIC interaction).

\subsection{Effects of intra-VTA 2-hydroxysaclofen injections on shock- and intra-VTA CRF-induced reinstatement}

In contrast to bicuculline, bilateral injections of the $G A B A_{B}$ receptor antagonist, 2-hydroxysaclofen, into the VTA prevented reinstatement in response to either shock delivery or intra-VTA CRF. The effects of intra-VTA injections of the two 2-hydroxysaclofen concentrations tested $(0.2 \mu \mathrm{g} /$ side and $2 \mu \mathrm{g} / \mathrm{side})$ on shock-induced cocaine seeking are shown in Fig. 5. Separate 2-way repeated measures (reinstatement $x$ drug treatment) ANOVAs were conducted for each 2-hydroxysaclofen concentration. In both cases significant overall shock-induced reinstatement $\left(0.2 \mu \mathrm{g} / \mathrm{side}: \mathrm{F}_{1,4}=153.84\right.$, $\left.\mathrm{P}<0.001, \mathrm{n}=5 ; 2 \mu \mathrm{g} / \mathrm{side}: \mathrm{F}_{1,7}=14.322, \mathrm{P}<0.01, \mathrm{n}=8\right)$ and significant interactions between 2-hydroxysaclofen and shock-induced reinstatement $\left(0.2 \mu \mathrm{g} / \mathrm{side}: \mathrm{F}_{1,4}=91.274, \mathrm{P}=0.001, \mathrm{n}=5\right.$;

$\left.2 \mu \mathrm{g} / \mathrm{side}: F_{1,7}=6.666, \mathrm{P}<0.05\right)$ were observed. Post-hoc testing showed that there was significant shock-induced reinstatement in rats pretreated with intra-VTA vehicle $(P<0.05)$ but not with either 2hydroxysaclofen dose. Moreover, reinstatement following intra-VTA 2hydroxysaclofen was significantly lower than following vehicle $(0.2$ $\mu \mathrm{g} /$ side, $\mathrm{P}<0.05 ; 2 \mu \mathrm{g} /$ side, $\mathrm{P}=0.05)$. 

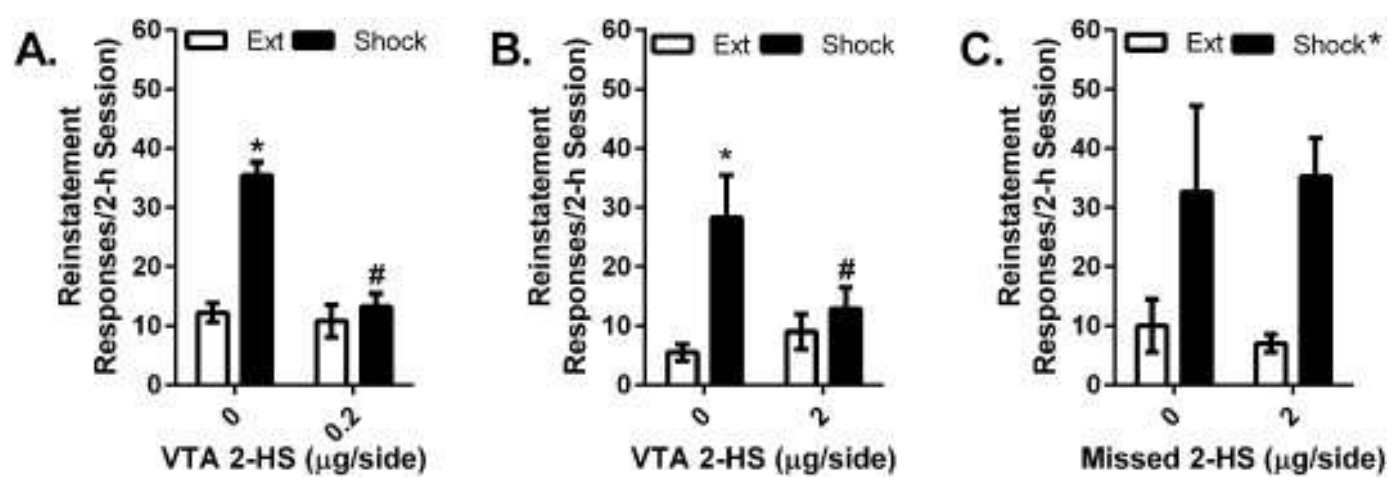

Fig. 5. Effects of intra-VTA 2-hydroxysaclofen injections on shock-induced reinstatement. Data represent responding (lever presses/2-h session \pm S.E.) recorded during reinstatement testing following electric footshock $\left(0.5 \mathrm{~mA}, 0.5^{\prime \prime}\right.$ shocks delivered an average of every $40 \mathrm{~s}$ over a 15 -min period) in rats pretreated with intraVTA injections of vehicle or $0.2 \mu \mathrm{g} /$ side $(A)$ or $2 \mu \mathrm{g} /$ side $(B)$ of the $G A B A_{B}$ receptor antagonist, 2-hydroxysaclofen (2-HS) and responding during the previous extinction (Ext) session. Shock reinstated cocaine seeking following vehicle $(0 \mu \mathrm{g} / \mathrm{side})$ pretreatment $(* P<0.05 \mathrm{vs}$. Ext) but not following injections of 0.2 or $2 \mu \mathrm{g} / \mathrm{side} 2$ hydroxysaclofen into the VTA. Moreover, lever pressing during the reinstatement session following shock delivery was significantly lower in rats that received intra-VTA injections of 0.2 or $2 \mu \mathrm{g} /$ side 2 -hydroxysaclofen relative to rats pretreated with vehicle ( $\mathrm{P}<0.05 \mathrm{vs} .0 \mu \mathrm{g} / \mathrm{side}$ ). By contrast, in rats with misplaced cannula that received 2 hydroxysaclofen injections into brain regions adjacent to the VTA, 2-hydroxysaclofen $(2 \mu \mathrm{g} / \mathrm{side})$ failed to affects shock-induced reinstatement of cocaine seeking (C).

To confirm anatomical localization of 2-hydroxysaclofen effects to the VTA, we also examined shock-reinstatement in a separate group of rats that received $2 \mu \mathrm{g} /$ side 2 -hydroxysaclofen injections via guide cannula implanted into regions adjacent to the VTA ( $n=5$; Fig. $5 \mathrm{C})$. 2-hydroxysaclofen had no effect on shock-induced reinstatement in these rats. A 2-way ANOVA showed a significant overall reinstatement effect $\left(F_{1,4}=109.606, P<0.001\right)$ but no effect of 2-hydroxysaclofen and no reinstatement $\times 2$-hydroxysaclofen interaction.

The effects of intra-VTA injections of the two 2-hydroxysaclofen concentrations $(0.2 \mu \mathrm{g} /$ side and $2 \mu \mathrm{g} / \mathrm{side})$ on cocaine seeking in response to intra-VTA CRF are shown in Fig. 6. As was the case with shock, significant overall intra-VTA CRF-induced reinstatement $\left(500 \mathrm{ng} /\right.$ side: $\mathrm{F}_{1,4}=, \mathrm{P}<0.001, \mathrm{n}=5 ; 2 \mu \mathrm{g} /$ side: $\mathrm{F}_{1,7}=, \mathrm{P}<0.01$, $\mathrm{n}=8$ ) and significant interactions between 2-hydroxysaclofen and CRF-induced reinstatement $\left(0.2 \mu \mathrm{g} / \mathrm{side}: \mathrm{F}_{1,4}=\mathrm{P}=0.001, \mathrm{n}=5\right.$; $2 \mu \mathrm{g} /$ side: $F_{1,7}=, P<0.05$ ) were observed. Post-hoc testing showed that there was significant CRF-induced reinstatement in rats pretreated with intra-VTA vehicle $(P<0.05)$ but not but not with either 2 hydroxysaclofen dose. Additionally, reinstatement following intra-VTA 
2-hydroxysaclofen was significantly lower than that observed following vehicle pretreatment $(0.2 \mu \mathrm{g} /$ side, $\mathrm{P}<0.05 ; 2 \mu \mathrm{g} /$ side, $\mathrm{P}=0.05)$.
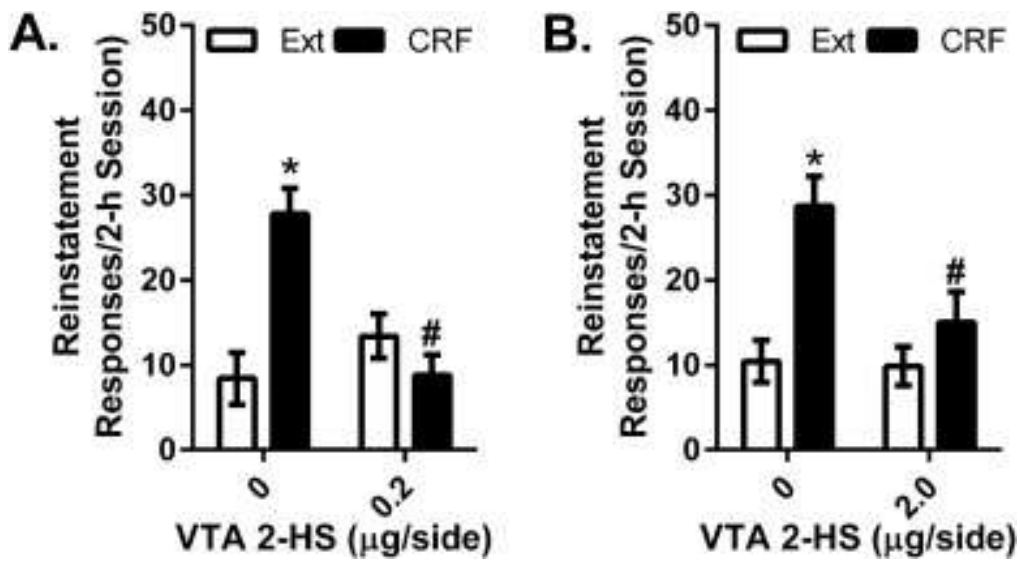

Fig. 6. Effects of intra-VTA 2-hydroxysaclofen injections on CRF-induced reinstatement of extinguished cocaine seeking. Data represent responding (lever presses/2-h session \pm S.E.) following bilateral intra-VTA administration of CRF (500 $\mathrm{ng} / \mathrm{side}$ ) in rats pretreated with intra-VTA injections of vehicle or the $0.2 \mu \mathrm{g} / \mathrm{side}$ (A) or $2 \mu \mathrm{g} /$ side (B) concentration of the $\mathrm{GABA}_{B}$ receptor antagonist, 2hydroxysaclofen (2-HS) and responding during the previous extinction (Ext) session. Intra-VTA CRF reinstated cocaine seeking following vehicle $(0 \mu \mathrm{g} / \mathrm{side})$ pretreatment ( $* P<0.05$ vs. Ext) but not following pretreatment with 0.2 or $2 \mu \mathrm{g} / \mathrm{side} 2$ hydroxysaclofen. Moreover, lever pressing during the reinstatement session following CRF administration was significantly lower in rats pretreated with 0.2 or $2 \mu \mathrm{g} / \mathrm{side} 2$ hydroxysaclofen relative to rats pretreated with vehicle ( $\left.{ }^{\#} P<0.05 \mathrm{vs} .0 \mu \mathrm{g} / \mathrm{side}\right)$.

\subsection{Effects of intra-VTA bicuculline or 2- hydroxysaclofen injections on food-reinforced responding}

To determine if non-specific behavioral suppression contributed to effects on cocaine seeking, separate groups of rats were tested for effects of intra-VTA drug (10 or $20 \mathrm{ng} /$ side bicuculline or 0.2 or $2 \mu \mathrm{g} /$ side 2-hydroxysaclofen) or vehicle administration on leverpressing reinforced by sucrose-sweetened food pellets during a 30-min session (Table $2 ; n=4-6 /$ group). Two-way testing (baseline vs. test session preceded by VTA injection; within subjects) $\times$ drug (drug vs. vehicle; between subjects) ANOVAs failed to show effects of injection of any of the drugs into the VTA on food-reinforced responding (no significant effects of testing or drug or testing $\times$ drug interactions were observed.

Neuropharmacology, Vol 102 (March 2016): pg. 197-206. DOI. This article is @ Elsevier and permission has been granted for this version to appear in e-Publications@Marquette. Elsevier does not grant permission for this article to be further copied/distributed or hosted elsewhere without the express permission from Elsevier. 
Table 2. Effects of intra-VTA bicuculline or 2-HS injections on food-reinforced lever pressing. Data represent the numbers of sucrose-sweetened food pellet-reinforced lever presses during the 30-min session following bilateral intra-VTA injections of vehicle $(n=6), 10 n g /$ side bicuculline $(n=4), 20 \mathrm{ng} /$ side bicuculline $(n=4), 0.2 \mu \mathrm{g}$ 2-hydroxysaclofen $(n=4)$, or $2 \mu \mathrm{g} 2$-hydroxysaclofen $(n=4)$ or during the preceding baseline session (Bas). Food-reinforced responding was not significantly altered by any of the VTA treatments.

\begin{tabular}{|c|c|c|c|c|c|c|c|c|c|c|}
\hline \multirow[t]{2}{*}{$\begin{array}{l}\text { Intra-VTA } \\
\text { treatment }\end{array}$} & \multicolumn{2}{|c|}{ Vehicle } & \multicolumn{2}{|c|}{$\begin{array}{l}\text { Bicuculline } \\
\text { (10 ng/side) }\end{array}$} & \multicolumn{2}{|c|}{$\begin{array}{l}\text { Bicuculline } \\
\text { (20 ng/side) }\end{array}$} & \multicolumn{2}{|c|}{$(0.2 \mathrm{\mu g} / \mathrm{side}$} & \multicolumn{2}{|c|}{$\begin{array}{c}\text { 2-HS } \\
(2 \mathrm{\mu g} / \mathrm{side})\end{array}$} \\
\hline & Bas & Veh & $\mathrm{Ba}$ & Bic & Bas & c & & & & 2-HS \\
\hline $\begin{array}{l}\text { espc } \\
\text { in }\end{array}$ & $\begin{array}{l}304.4 \\
( \pm 17.5 \\
)\end{array}$ & $\begin{array}{l}307.3 \\
( \pm 17.9 \\
)\end{array}$ & $\begin{array}{l}330.5 \\
( \pm 28.7 \\
)\end{array}$ & $\begin{array}{l}340.0 \\
( \pm 17.9 \\
)\end{array}$ & $\begin{array}{l}327.2 \\
( \pm 28.7\end{array}$ & $\begin{array}{l}340.0 \\
( \pm 27.6\end{array}$ & $\begin{array}{l}30 \\
( \pm\end{array}$ & $\begin{array}{l}303.0 \\
( \pm 13.7\end{array}$ & $\begin{array}{l}293.0 \\
( \pm 25.4 \\
4)\end{array}$ & $\begin{array}{l}286.0 \\
( \pm 34.8 \\
9)\end{array}$ \\
\hline
\end{tabular}

\section{Discussion}

Our results demonstrate that intra-VTA injections of the GABA receptor antagonist, 2-hydroxysaclofen, prevent reinstatement in response to either footshock stress or intra-VTA delivery of the stressor-responsive neuropeptide, CRF. These effects were observed at 2-hydroxysaclofen doses that did not alter lever pressing reinforced by sucrose-sweetened food pellets and did not affect cocaine seeking in the absence of stress or CRF. By contrast, intra-VTA injections of the $\mathrm{GABA}_{\mathrm{A}}$ receptor antagonist, bicuculline across a range of doses, had no effects on shock- or CRF-induced reinstatement. Thus, the results suggest that 1) GABA release into the VTA and $\mathrm{GABA}_{B}$ receptor activation are necessary for stress-induced cocaine seeking and 2) in the VTA, GABA $\mathrm{B}_{\mathrm{B}}$ receptor activation is required for local CRF effects that underlie stress-induced cocaine seeking.

The ventral tegmental area (VTA) is a key site at which inputs from a number of stress-responsive brain regions converge to regulate motivated behavior and reward and promote relapse to drug use in addicts. Understanding the mechanisms in the VTA through which stressors trigger cocaine use should facilitate the development of new and more effective treatment strategies. We and others have previously reported that CRF actions in the VTA are required for stressinduced reinstatement following cocaine self-administration and that CRF delivery into the VTA is sufficient induce cocaine seeking (Wang et al., 2005, Wang et al., 2007, Blacktop et al., 2011 and Vranjkovic et al., 2014). These actions have been reported to involve both CRFR1 (Blacktop et al., 2011 and Chen et al., 2014) and CRF-R2 (Wang 
et al., 2005 and Wang et al., 2007) receptors as well an interaction with the CRF binding protein (Wang et al., 2007). As is the case with many neuropeptides, the cellular effects of CRF in the VTA appear to involve a complex coordination of cellular function through a wide array of actions at presynaptic, postsynaptic and extrasynaptic sites.

Much of the research examining CRF actions in the VTA has focused on its enhancement of excitatory neurotransmission (Wise and Morales, 2010). CRF directly excites dopamine and non-dopamine neurons in the VTA (Korotkova et al., 2006 and Wanat et al., 2008) and indirectly facilitates excitatory synaptic transmission in the VTA through post-synaptic trafficking of NMDA and AMPA receptors (Ungless et al., 2003 and Hahn et al., 2009) and promotion of glutamate release (Wang et al., 2005 and Hahn et al., 2009). Stressinduced reinstatement following cocaine (Wang et al., 2005) or heroin SA (Wang et al., 2012) is associated with increased VTA glutamate levels, while intra-VTA delivery of kynurenic acid, an ionotropic glutamate receptor antagonist, prevents stress-induced reinstatement and corresponding increases in VTA dopamine levels (Wang et al., 2005 and Wang et al., 2012).

Less attention has been given to the role of VTA GABAergic neurotransmission in stress-induced drug seeking. Delivery of a combination of the $\mathrm{GABA}_{A}$ receptor agonist, muscimol, and the $\mathrm{GABA}_{B}$ receptor agonist, baclofen, into the VTA attenuates cocaine seeking in response to a number of stimuli, including a cocaine priming injection (McFarland and Kalivas, 2001), a cocaine-paired conditioned stimulus (Di Ciano and Everitt, 2004), and footshock stress (McFarland et al., 2004). However, while these studies implicate the VTA in cocaine seeking, they provide limited mechanistic information regarding the precise role of GABA as they do not differentiate between the contributions of $G A B A_{A}$ versus $G_{B B A}$ receptors and since, in contrast to agonist-based approaches, they do not differentiate between GABAergic mechanisms that are active during stress and those that are not.

The actions of GABA in the VTA are complex. The VTA receives GABAergic inputs from a number of brain regions, including the nucleus accumbens (Yim and Mogenson, 1980 and Bocklisch et al., 2013), periaqueductal gray (Omelchenko and Sesack, 2010), bed

Neuropharmacology, Vol 102 (March 2016): pg. 197-206. DOI. This article is @ Elsevier and permission has been granted for this version to appear in e-Publications@Marquette. Elsevier does not grant permission for this article to be further copied/distributed or hosted elsewhere without the express permission from Elsevier. 
nuclei of the stria terminalis (Kudo et al., 2012), lateral septum (Luo et al., 2011), laterodorsal tegmentum (Omelchenko and Sesack, 2005), ventral pallidum (Mahler et al., 2014), and rostromedial tegmental area (Jhou et al., 2009, Matsui and Williams, 2011 and Barrot et al., 2012). Moreover, VTA cell populations include GABAergic interneurons (Steffensen et al., 1998 and Cruz et al., 2004) and GABAergic projection neurons (Van Bockstaele and Pickel, 1995 and Carr and Sesack, 2000) that may provide collateral GABA mediated regulation within the region (Omelchenko and Sesack, 2009). Both $\mathrm{GABA}_{A}$ and $\mathrm{GABA}_{B}$ receptors are expressed on dopaminergic and non-dopaminergic cells in the VTA (Churchill et al., 1992, Wirtshafter and Sheppard, 2001, Okada et al., 2004 and Ciccarelli et al., 2012) where they can regulate excitability, signaling and neurotransmitter release (see Creed et al., 2014 for review).

Stress-induced cocaine seeking is associated with altered GABAergic synaptic transmission in the VTA (Graziane et al., 2013). However, the mechanism through which GABAergic signaling contributes to cocaine seeking and its relationship to CRF has not been previously reported. It has been suggested that CRF-releasing terminals in the VTA, at least those that innervate dopamine neurons, are predominantly glutamatergic, based on synaptic morphology (Tagliaferro and Morales, 2008). However, as is the case with most neuropeptides, regional diffusion of CRF to sites that regulate GABAergic transmission is likely. CRF has been reported to promote inhibitory transmission in a number of other brain regions including the central amygdala (Nie et al., 2004, Bajo et al., 2008 and Roberto et al., 2010), dorsal raphe nucleus (Waselus et al., 2005 and Kirby et al., 2008) and bed nucleus of the stria terminalis (Kash and Winder, 2006). In the VTA, CRF promotes GABA release via presynaptic receptor actions (Williams et al., 2014) as well as excitation of intrinsic GABA interneurons (Korotkova et al., 2006) and, through a

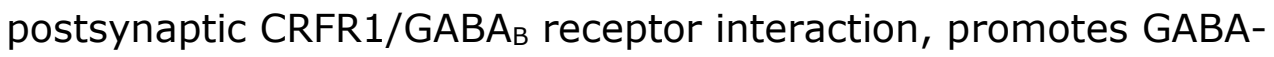
induced GIRK-mediated inhibitory postsynaptic currents (Beckstead et al., 2009). Thus, the blockade of stress-induced cocaine seeking by 2-hydroxysaclofen could be attributable to 1) preventing the activation of $\mathrm{GABA}_{B}$ receptors by GABA released in response to CRF and/or 2) disruption of a post-synaptic interactions between $C R F$ and $G_{A B A}$ receptors.

Neuropharmacology, Vol 102 (March 2016): pg. 197-206. DOI. This article is (C Elsevier and permission has been granted for this version to appear in e-Publications@Marquette. Elsevier does not grant permission for this article to be further copied/distributed or hosted elsewhere without the express permission from Elsevier. 
The exact mechanism through which CRF interacts with $G_{A B A}$ receptors in the VTA to promote cocaine seeking is unclear but likely involves one of several possibilities. First, $\mathrm{GABA}_{B}$ receptor activation could inhibit VTA GABAergic interneurons, thereby disinhibiting dopamine neurons that project to terminal field regions involved in stress-induced drug seeking such as the prelimbic cortex (Capriles et al., 2003 and McFarland et al., 2004) and nucleus accumbens (Shaham and Stewart, 1996 and Xi et al., 2004). It has been reported that, in contrast to VTA dopamine neurons, which are relatively insensitive to inhibition by the $\mathrm{GABA}_{B}$ receptor agonist, baclofen, VTA GABA neurons are much more susceptible to baclofen inhibition (Bonci and Malenka, 1999 and Cruz et al., 2004; but see Margolis et al.,

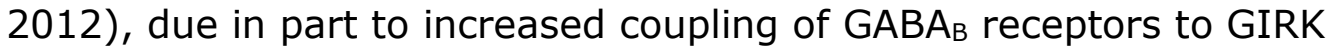
channels (Cruz et al., 2004). In fact, long-term potentiation at inhibitory synapses between descending D1 receptor-expressing nucleus accumbens GABAergic medium spiny neurons and VTA GABAergic interneurons, and the resulting downstream disinhibition of VTA dopamine neurons, have been shown to contribute to cocaineinduced increases in dopamine neuronal excitability (Bocklisch et al., 2013), while GABA-mediated interneuron suppression and the resulting of disinhibition of dopamine neurons have been proposed to underlie context-induced reinstatement of cocaine seeking (Luo et al., 2011). Thus, to the extent that CRF selectively regulates GABAergic synapses on local interneurons via $G_{A B A}$ receptors, CRF inhibition of local interneuron populations and disinhibition of dopaminergic neurons could account for its effects on cocaine seeking. While intriguing, this possibility is inconsistent with the finding that VTA $\mathrm{GABA}_{B}$ receptor antagonism does not decrease but rather increases the nucleus accumbens dopamine response to stress (Doherty and Gratton, 2007) and tends to be inconsistent with our own finding that VTA GABA $A_{A}$ receptor antagonism using bicuculline, which should reproduce any effects of 2-hydroxysaclofen-mediated inhibition of VTA GABAergic interneurons, does not reinstate cocaine seeking.

Alternatively, shock, via CRF, could promote GABA actions to decrease or alter the pattern of firing of VTA dopamine neurons, thereby promoting cocaine seeking. Indeed, Tan et al. (2012) have reported that footshock excites VTA GABA interneurons while also inhibiting of a large majority of dopamine neurons, consistent with reports that, while footshock activates a subpopulation of dopamine for this version to appear in e-Publications@Marquette. Elsevier does not grant permission for this article to be further copied/distributed or hosted elsewhere without the express permission from Elsevier. 
neurons (Brischoux et al., 2009), most VTA neurons show a shockinduced reduction in firing (Ungless et al., 2004). These findings are paralleled by reports that aversive stimuli often produce time-locked decreases in nucleus accumbens dopamine release, as measured using voltammetry (Badrinarayan et al., 2012, Roitman et al., 2008 and Oleson et al., 2012). While the possibility that stressors can promote cocaine seeking via reductions in the activity of mesolimbic dopamine neurons is inconsistent with the assumption that stressinduced drug seeking is mediated by elevated dopamine in the nucleus accumbens (Shaham and Stewart, 1996 and Xi et al., 2004; but see McFarland et al., 2004), we have recently reported that an aversive stimulus (intra-oral quinine delivery) that reduces dopamine levels in nucleus accumbens shell can reinstate cocaine seeking following selfadministration in rats (Twining et al., 2015). Moreover, both quinineinduced cocaine seeking and quinine-induced reductions in nucleus accumbens dopamine levels are dependent on VTA CRF receptor activation (Twining et al., 2015).

Another possibility is that the effects 2-hydroxysaclofen on cocaine seeking are attributable to antagonism of presynaptic GABA receptors on the terminals of afferent projections into the VTA. It is well established that presynaptic $\mathrm{GABA}_{B}$ receptors are important regulators of vesicular neurotransmitter release (see e.g., Takahashi et al., 1998, Sakaba and Neher, 2003 and Padgett and Slesinger, 2010) and, in the VTA, GABA ${ }_{B}$ receptors have been reported to regulate both GABA (Chen et al., 2015) and glutamate (Padgett et al., 2012) release. Cocaine seeking and dopamine neurons in the VTA are negatively regulated by GABAergic efferents from several brain regions, including the ventral pallidum (Mahler et al., 2014) and the rostromedial tegmental area (Huff and LaLumiere, 2015). Thus, it is possible that $G_{A B A_{B}}$ antagonism disinhibits these afferents, thereby promoting GABA release and $\mathrm{GABA}_{\mathrm{A}}$ receptor-mediated inhibition of dopaminergic neurons and cocaine seeking. As would be the case with interneuron inhibition, our finding that intra-VTA bicuculline does not increase cocaine seeking would suggest that, to the extent that this mechanism applies, GABAergic inputs are not providing baseline tonic inhibition of dopamine neurons in the VTA.

Alternatively, CRF-induced GABA release may exert heterosynaptic effects via $\mathrm{GABA}_{\mathrm{B}}$ receptors to regulate glutamatergic

Neuropharmacology, Vol 102 (March 2016): pg. 197-206. DOI. This article is @ Elsevier and permission has been granted for this version to appear in e-Publications@Marquette. Elsevier does not grant permission for this article to be further copied/distributed or hosted elsewhere without the express permission from Elsevier. 
transmission (Manzoni and Williams, 1999). Riegel and colleagues (Williams et al., 2014) have reported that CRF, via CRF-R2 receptormediated effects on GABA release, can promote $G A B A_{B}$ receptor activation on glutamatergic terminals, thereby attenuating glutamate release and offsetting CRF-R1 receptor mediated increases in excitatory regulation of VTA dopamine neurons. It has been hypothesized that, following cocaine self-administration, this CRF-R2 receptor-driven inhibitory effect of GABA on excitatory transmission diminishes, resulting in a shift from inhibitory to excitatory regulation of dopamine neurons by CRF. While this represents an interesting mechanism through which CRF can regulate VTA dopamine neurons, according to this model, CRF effects on glutamatergic transmission in the VTA are no longer $\mathrm{GABA}_{B}$ receptor-dependent after cocaine selfadministration. Moreover, it is not clear how $\mathrm{GABA}_{\mathrm{B}}$ receptor attenuation of excitatory neurotransmission would result in reinstatement. Notably, an important distinction between that study and ours is the use of yohimbine in combination with non-extinguished response-contingent cocaine-associated cues as reinstating stimuli which may involve unique neurocircuitry and/or activate VTA inputs in addition to those that are stimulated by stress alone. Nonetheless, this proposed mechanism does not seem to account for our current findings.

When considering the possible contribution of VTA GABA to cocaine seeking it is also important to recognize that the regulation of neuronal firing patterns in the VTA by GABA is complex and does not necessarily result exclusively in inhibition of efferent pathways. Transient GABA-mediated inhibition may coordinate or synchronize regional network activity and/or prime neurons for excitation and burst firing. Indeed, it has been reported that GABAergic transmission in the VTA is critical for nicotine-induced excitation of dopamine neurons and associated behavioral responses (Tolu et al., 2013).

Neither administration of bicuculline nor 2-hydroxysaclofen into the VTA alone was sufficient to induce cocaine seeking. Although reinstatement by intra-VTA bicuculline or 2-hydroxysaclofen has not, to our knowledge, been previously reported, these results were somewhat surprising to us, particularly in the case of bicuculline, which has been found to elevate nucleus accumbens dopamine levels (Ikemoto et al., 1997), increase locomotor activity (Grubb et al., 
2002 and Lavezzi et al., 2015), and produce conditioned place preference (Laviolette and van der Kooy, 2001) when injected into the VTA and has been reported to be self-administered directly into the VTA in mice (David et al., 1997). As elevated dopamine in the nucleus accumbens (Cornish and Kalivas, 2000) and intra-accumbens delivery of dopamine receptor agonists (Bachtell et al., 2005 and Schmidt et al., 2006) have been reported to be sufficient for reinstatement of cocaine seeking, we predicted that intra-VTA GABA receptor antagonism would induce cocaine seeking, especially considering that GABA receptor agonist injections into the VTA suppress dopamine release (Yoshida et al., 1994), drug self-administration (Xi and Stein, 1999, Brebner et al., 2000 and Backes and Hemby, 2008), and reinstatement (McFarland and Kalivas, 2001, Di Ciano and Everitt, 2004 and McFarland et al., 2004). When considering the failure of GABA antagonists to induced cocaine seeking, the complexity of GABAergic regulation of the VTA and the understanding that distinct mechanisms contribute to reinforcement/reward vs. motivation/seeking should be taken into account. While it is possible that the antagonist doses used were insufficient to effectively target GABA receptors, we consider this unlikely, as the same 2hydroxysaclofen doses attenuated reinstatement and we were unable to test higher intra-VTA bicuculline doses due to the emergence of seizure activity, as has been previously described (Echo et al., 2002).

To confirm that any GABA receptor antagonist effects on reinstatement were not attributable to non-specific behavioral disruption, separate groups of rats were tested for effects of intra-VTA antagonist injections on food-reinforced lever pressing. Neither bicuculline nor 2-hydroxysaclofen altered food-reinforced responding, suggesting that motor impairment likely did not contribute to 2hydroxysaclofen-induced reductions in shock- and CRF-induced reinstatement. Considering that optogenetic stimulation of VTA GABA neurons impairs natural reward consumption (van Zessen et al., 2012), it is somewhat surprising that effects on food-reinforced responding were not observed. However, consistent with our findings, others have reported that $G A B A_{A}$ and $G A B A_{B}$ receptor antagonism in the VTA has minimal effects on feeding behavior (Echo et al., 2002, Ackerman et al., 2003 and Miner et al., 2010). When interpreting these findings, it is important to note that the rates of responding during the food-reinforced sessions (approximately 30

Neuropharmacology, Vol 102 (March 2016): pg. 197-206. DOI. This article is (C Elsevier and permission has been granted for this version to appear in e-Publications@Marquette. Elsevier does not grant permission for this article to be further copied/distributed or hosted elsewhere without the express permission from Elsevier. 
responses/minute) were much higher than those during the reinstatement sessions. For this reason, less-pronounced disruption of motor performance that could have contributed to the observed effects on cocaine seeking or increases in responding attributable to enhancement of food reward may not have been detectable under these conditions.

\section{Conclusion}

To summarize, our results suggest that stress-induced reinstatement of extinguished cocaine seeking requires VTA GABA receptor activation, likely via a CRF-regulated mechanism. While the precise process through which $C R F$ interacts with $G_{A B A_{B}}$ receptors remains to be determined, these findings provide novel insight into mechanisms that contribute to stress-induced relapse and therefore may guide the development of new therapeutic approaches aimed at relapse prevention.

\section{Acknowledgments}

This work was supported by National Institute on Drug Abuse (NIDA) grant number DA15758 to John R. Mantsch. The authors acknowledge Chris Mueller for his technical assistance.

\section{References}

Ackerman et al., 2003. T.F. Ackerman, N. Lamonte, R.J. Bodnar. Lack of intersite GABA receptor subtype antagonist effects upon mu opioid receptor agonist-induced feeding elicited from either the ventral tegmental area or nucleus accumbens shell in rats. Physiol. Behav., 79 (2003), pp. 191-198

Badrinarayan et al., 2012. A. Badrinarayan, S.A. Wescott, C.M. Vander Weele, B.T. Saunders, B.E. Couturier, S. Maren, B.J. Aragona. Aversive stimuli differentially modulate real-time dopamine transmission dynamics within the nucleus accumbens core and shell. J. Neurosci., 32 (2012), pp. $15779-15790$

Bachtell et al., 2005. R.K. Bachtell, K. Whisler, D. Karanian, D.W. Self. Effects of intra-nucleus accumbens shell administration of dopamine agonists and antagonists on cocaine-taking and cocaine-seeking behaviors in the rat. Psychopharmacology, 183 (2005), pp. 41-53

Neuropharmacology, Vol 102 (March 2016): pg. 197-206. DOI. This article is @ Elsevier and permission has been granted for this version to appear in e-Publications@Marquette. Elsevier does not grant permission for this article to be further copied/distributed or hosted elsewhere without the express permission from Elsevier. 
Backes and Hemby, 2008. E.N. Backes, S.E. Hemby. Contribution of ventral tegmental GABA receptors to cocaine self-administration in rats. Neurochem. Res., 33 (2008), pp. 459-467

Bajo et al., 2008. M. Bajo, M.T. Cruz, G.R. Siggins, R. Messing, M. Roberto. Protein kinase $C$ epsilon mediation of CRF- and ethanol-induced GABA release in central amygdala. Proc. Natl. Acad. Sci. U. S. A., 105 (2008), pp. 8410-8415

Barrot et al., 2012. M. Barrot, S.R. Sesack, F. Georges, M. Pistis, S. Hong, T.C. Jhou. Braking dopamine systems: a new GABA master structure for mesolimbic and nigrostriatal functions. J. Neurosci., 32 (2012), pp. 14094-14101

Beckstead et al., 2009. M.J. Beckstead, S.C. Gantz, C.P. Ford, M.P. StenzelPoore, P.E. Phillips, G.P. Mark, J.T. Williams. CRF enhancement of GIRK channel-mediated transmission in dopamine neurons. Neuropsychopharmacol, 34 (2009), pp. 1926-1935

Blacktop et al., 2011. J.M. Blacktop, C. Seubert, D.A. Baker, N. Ferda, G. Lee, E.N. Graf, J.R. Mantsch. Augmented cocaine seeking in response to stress or CRF delivered into the ventral tegmental area following longaccess self-administration is mediated by CRF receptor type 1 but not CRF receptor type 2. J. Neurosci., 31 (2011), pp. 11396-11403

Bocklisch et al., 2013. C. Bocklisch, V. Pascoli, J.C. Wong, D.R. House, C. Yvon, M. de Roo, K.R. Tan, C. Lüscher. Cocaine disinhibits dopamine neurons by potentiation of GABA transmission in the ventral tegmental area. Science, 341 (2013), pp. 1521-1525

Bonci and Malenka, 1999. A. Bonci, R.C. Malenka. Properties and plasticity of excitatory synapses on dopaminergic and GABAergic cells in the ventral tegmental area. J. Neurosci., 19 (1999), pp. 3723-3730

Brebner et al., 2000. K. Brebner, R. Phelan, D.C. Roberts. Intra-VTA baclofen attenuates cocaine self-administration on a progressive ratio schedule of reinforcement. Pharmacol. Biochem. Behav., 66 (2000), pp. 857862

Brischoux et al., 2009. F. Brischoux, S. Chakraborty, D.I. Brierley, M.A. Ungless. Phasic excitation of dopamine neurons in ventral VTA by noxious stimuli. Proc. Natl. Acad. Sci. U. S. A., 106 (2009), pp. 48944899

Capriles et al., 2003. N. Capriles, D. Rodaros, R.E. Sorge, J. Stewart. A role for the prefrontal cortex in stress- and cocaine-induced reinstatement of cocaine seeking in rats. Psychopharmacology, 168 (2003), pp. 6674

Carr and Sesack, 2000. D.B. Carr, S.R. Sesack. GABA-containing neurons in the rat ventral tegmental area project to the prefrontal cortex. Synapse, 38 (2000), pp. 114-123

Neuropharmacology, Vol 102 (March 2016): pg. 197-206. DOI. This article is @ Elsevier and permission has been granted for this version to appear in e-Publications@Marquette. Elsevier does not grant permission for this article to be further copied/distributed or hosted elsewhere without the express permission from Elsevier. 
Chen et al., 2014. N.A. Chen, B. Jupp, Y. Sztainberg, M. Lebow, R.M. Brown, J.H. Kim, A. Chen, A.J. Lawrence. Knockdown of CRF1 receptors in the ventral tegmental area attenuates cue- and acute food deprivation stress-induced cocaine seeking in mice. J. Neurosci., 34 (2014), pp. $11560-11570$

Chen et al., 2015. M. Chen, Y. Zhao, H. Yang, W. Luan, J. Song, D. Cui, Y. Dong, B. Lai, L. Ma, P. Zheng. Morphine disinhibits glutamatergic input to VTA dopamine neurons and promotes dopamine neuron excitation. Elife, 4 (2015) http://dx.doi.org/10.7554/eLife.09275

Churchill et al., 1992. L. Churchill, R.P. Dilts, P.W. Kalivas. Autoradiographic localization of gamma-aminobutyric acidA receptors within the ventral tegmental area. Neurochem. Res., 17 (1992), pp. 101-106

Ciccarelli et al., 2012. A. Ciccarelli, A. Calza, P. Panzanelli, A. Concas, M. Giustetto, M. Sassoè-Pognetto. Organization of GABAergic synaptic circuits in the rat ventral tegmental area. PLoS One, 7 (2012), p. e46250

Cornish and Kalivas, 2000. J.L. Cornish, P.W. Kalivas. Glutamate transmission in the nucleus accumbens mediates relapse in cocaine addiction. J. Neurosci., 20 (2000), p. RC89

Creed et al., 2014. M.C. Creed, N.R. Ntamati, K.R. Tan. VTA GABA neurons modulate specific learning behaviors through the control of dopamine and cholinergic systems. Front. Behav. Neurosci., 8 (2014), p. 8

Cruz et al., 2004. H.G. Cruz, T. Ivanova, M.L. Lunn, M. Stoffel, P.A. Slesinger, C. Lüscher. Bi-directional effects of $G A B A(B)$ receptor agonists on the mesolimbic dopamine system. Nat. Neurosci., 7 (2004), pp. 153-159

David et al., 1997. V. David, T.P. Durkin, P. Cazala. Self-administration of the GABAA antagonist bicuculline into the ventral tegmental area in mice: dependence on D2 dopaminergic mechanisms. Psychopharmacology, 130 (1997), pp. 85-90

Di Ciano and Everitt, 2004. P. Di Ciano, B.J. Everitt. Contribution of the ventral tegmental area to cocaine-seeking maintained by a drug-paired conditioned stimulus in rats. Eur. J. Neurosci., 19 (2004), pp. 16611667

Doherty and Gratton, 2007. M. Doherty, A. Gratton. Differential involvement of ventral tegmental $\mathrm{GABA}(\mathrm{A})$ and $\mathrm{GABA}(\mathrm{B})$ receptors in the regulation of the nucleus accumbens dopamine response to stress. Brain Res., 1150 (2007), pp. 62-68

Echo et al., 2002. J.A. Echo, N. Lamonte, T.F. Ackerman, R.J. Bodnar. Alterations in food intake elicited by GABA and opioid agonists and antagonists administered into the ventral tegmental area region of rats. Physiol. Behav., 76 (2002), pp. 107-116

Erb and Stewart, 1999. S. Erb, J. Stewart. A role for the bed nucleus of the stria terminalis, but not the amygdala, in the effects of corticotropin-

Neuropharmacology, Vol 102 (March 2016): pg. 197-206. DOI. This article is @ Elsevier and permission has been granted for this version to appear in e-Publications@Marquette. Elsevier does not grant permission for this article to be further copied/distributed or hosted elsewhere without the express permission from Elsevier. 
NOT THE PUBLISHED VERSION; this is the author's final, peer-reviewed manuscript. The published version may be accessed by following the link in the citation at the bottom of the page.

releasing factor on stress-induced reinstatement of cocaine seeking. J. Neurosci., 19 (1999), p. RC35

Fox et al., 2005. H.C. Fox, M. Talih, R. Malison, G.M. Anderson, M.J. Kreek, R. Sinha. Frequency of recent cocaine and alcohol use affects drug craving and associated responses to stress and drug-related cues. Psychoneuroendocrinology, 30 (2005), pp. 880-891

Graziane et al., 2013. N.M. Graziane, A.M. Polter, L.A. Briand, R.C. Pierce, J.A. Kauer. Kappa opioid receptors regulate stress-induced cocaine seeking and synaptic plasticity. Neuron, 77 (2013), pp. 942-954

Grubb et al., 2002. M.C. Grubb, J.R. Welch, D.A. Finn, G.P. Mark. Cocaine self-administration alters the locomotor response to microinjection of bicuculline into the ventral tegmental area of rats. Brain Res., 952 (2002), pp. 44-51

Hahn et al., 2009. J. Hahn, F.W. Hopf, A. Bonci. Chronic cocaine enhances corticotropin-releasing factor-dependent potentiation of excitatory transmission in ventral tegmental area dopamine neurons.

J. Neurosci., 29 (2009), pp. 6535-6544

Huff and LaLumiere, 2015. M.L. Huff, R.T. LaLumiere. The rostromedial tegmental nucleus modulates behavioral inhibition following cocaine self-administration in rats. Neuropsychopharmacology, 40 (2015), pp. 861-873

Ikemoto et al., 1997. S. Ikemoto, R.R. Kohl, W.J. McBride. GABA(A) receptor blockade in the anterior ventral tegmental area increases extracellular levels of dopamine in the nucleus accumbens of rats. J. Neurochem., 69 (1997), pp. 137-143

Jhou et al., 2009. T.C. Jhou, H.L. Fields, M.G. Baxter, C.B. Saper, P.C. Holland. The rostromedial tegmental nucleus (RMTg), a GABAergic afferent to midbrain dopamine neurons, encodes aversive stimuli and inhibits motor responses. Neuron, 61 (2009), pp. 786-800

Kash and Winder, 2006. T.L. Kash, D.G. Winder. Neuropeptide $Y$ and corticotropin-releasing factor bi-directionally modulate inhibitory synaptic transmission in the bed nucleus of the stria terminalis. Neuropharmacology, 51 (2006), pp. 1013-1022

Kirby et al., 2008. L.G. Kirby, E. Freeman-Daniels, J.C. Lemos, J.D. Nunan, C. Lamy, A. Akanwa, S.G. Beck. Corticotropin-releasing factor increases GABA synaptic activity and induces inward current in 5hydroxytryptamine dorsal raphe neurons. J. Neurosci., 28 (2008), pp. 12927-12937

Korotkova et al., 2006. T.M. Korotkova, R.E. Brown, O.A. Sergeeva, A.A. Ponomarenko, H.L. Haas. Effects of arousal- and feeding-related neuropeptides on dopaminergic and GABAergic neurons in the ventral tegmental area of the rat. Eur. J. Neurosci., 23 (2006), pp. 2677-2685

Neuropharmacology, Vol 102 (March 2016): pg. 197-206. DOI. This article is @ Elsevier and permission has been granted for this version to appear in e-Publications@Marquette. Elsevier does not grant permission for this article to be further copied/distributed or hosted elsewhere without the express permission from Elsevier. 
Kudo et al., 2012. T. Kudo, M. Uchigashima, T. Miyazaki, K. Konno, M. Yamasaki, Y. Yanagawa, M. Minami, M. Watanabe. Three types of neurochemical projection from the bed nucleus of the stria terminalis to the ventral tegmental area in adult mice. J. Neurosci., 32 (2012), pp. $18035-18046$

Lavezzi et al., 2015. H.N. Lavezzi, K.P. Parsley, D.A. Zahm. Modulation of locomotor activation by the rostromedial tegmental nucleus. Neuropsychopharmacology, 40 (2015), pp. 676-687

Laviolette and van der Kooy, 2001. S.R. Laviolette, D. van der Kooy. GABA(A) receptors in the ventral tegmental area control bidirectional reward signaling between dopaminergic and non-dopaminergic neural motivational systems. Eur. J. Neurosci., 13 (2001), pp. 1009-1015

Luo et al., 2011. A.H. Luo, P. Tahsili-Fahadan, R.A. Wise, C.R. Lupica, G. Aston-Jones. Linking context with reward: a functional circuit from hippocampal CA3 to ventral tegmental area. Science, 333 (2011), pp. 353-357

Mahler et al., 2014. S.V. Mahler, E.M. Vazey, J.T. Beckley, C.R. Keistler, E.M. McGlinchey, J. Kaufling, S.P. Wilson, K. Deisseroth, J.J. Woodward, G. Aston-Jones. Designer receptors show role for ventral pallidum input to ventral tegmental area in cocaine seeking. Nat. Neurosci., 17 (2014), pp. $577-585$

Mantsch et al., 2008. J.R. Mantsch, D.A. Baker, D.M. Francis, E.S. Katz, M.A. Hoks, J.P. Serge. Stressor- and corticotropin releasing factor-induced reinstatement and active stress-related behavioral responses are augmented following long-access cocaine self-administration by rats. Psychopharmacology, 195 (2008), pp. 591-603

Mantsch et al., 2015. J.R. Mantsch, D.A. Baker, D. Funk, A.D. Lê, Y. Shaham. Stress-induced reinstatement of drug seeking: 20 years of progress. Neuropsychopharmacology (2015) http://dx.doi.org/10.1038/npp.2015.142

Manzoni and Williams, 1999. O.J. Manzoni, J.T. Williams. Presynaptic regulation of glutamate release in the ventral tegmental area during morphine withdrawal. J. Neurosci., 19 (1999), pp. 6629-6636

Margolis et al., 2012. E.B. Margolis, B. Toy, P. Himmels, M. Morales, H.L. Fields. Identification of rat ventral tegmental area GABAergic neurons. PLoS One, 7 (2012), p. e42365

Matsui and Williams, 2011. A. Matsui, J.T. Williams. Opioid-Sensitive GABA inputs from rostromedial tegmental nucleus synapse onto midbrain dopamine neurons. J. Neurosci., 31 (2011), pp. 17729-17735

McFarland and Kalivas, 2001. K. McFarland, P.W. Kalivas. The circuitry mediating cocaine-induced reinstatement of drug-seeking behavior. J. Neurosci., 21 (2001), pp. 8655-8663

Neuropharmacology, Vol 102 (March 2016): pg. 197-206. DOI. This article is (C) Elsevier and permission has been granted for this version to appear in e-Publications@Marquette. Elsevier does not grant permission for this article to be further copied/distributed or hosted elsewhere without the express permission from Elsevier. 
McFarland et al., 2004. K. McFarland, S.B. Davidge, C.C. Lapish, P.W. Kalivas. Limbic and motor circuitry underlying footshock-induced reinstatement of cocaine-seeking behavior. J. Neurosci., 24 (2004), pp. 1551-1560

Miner et al., 2010. P. Miner, Y. Borkuhova, L. Shimonova, A. Khaimov, R.J. Bodnar. GABA-A and GABA-B receptors mediate feeding elicited by the GABA-B agonist baclofen in the ventral tegmental area and nucleus accumbens shell in rats: reciprocal and regional interactions. Brain Res., 1355 (2010), pp. 86-96

Nie et al., 2004. Z. Nie, P. Schweitzer, A.J. Roberts, S.G. Madamba, S.D. Moore, G.R. Siggins. Ethanol augments GABAergic transmission in the central amygdala via CRF1 receptors. Science, 303 (2004), pp. 15122154

Okada et al., 2004. H. Okada, N. Matsushita, K. Kobayashi, K. Kobayashi. Identification of GABAA receptor subunit variants in midbrain dopaminergic neurons. J. Neurochem., 89 (2004), pp. 7-14

Oleson et al., 2012. E.B. Oleson, R.N. Gentry, V.C. Chioma, J.F. Cheer. Subsecond dopamine release in the nucleus accumbens predicts conditioned punishment and its successful avoidance. J. Neurosci., 32 (2012), pp. 14804-14808

Omelchenko and Sesack, 2005. N. Omelchenko, S.R. Sesack. Laterodorsal tegmental projections to identified cell populations in the rat ventral tegmental area. J. Comp. Neurol., 483 (2005), pp. 217-235

Omelchenko and Sesack, 2009. N. Omelchenko, S.R. Sesack. Ultrastructural analysis of local collaterals of rat ventral tegmental area neurons: GABA phenotype and synapses onto dopamine and GABA cells. Synapse, 63 (2009), pp. 895-906

Omelchenko and Sesack, 2010. N. Omelchenko, S.R. Sesack. Periaqueductal gray afferents synapse onto dopamine and GABA neurons in the rat ventral tegmental area. J. Neurosci. Res., 88 (2010), pp. 981-991

Padgett and Slesinger, 2010. C.L. Padgett, P.A. Slesinger. GABAB receptor coupling to G-proteins and ion channels. Adv. Pharmacol., 58 (2010), pp. $123-147$

Padgett et al., 2012. C.L. Padgett, A.L. Lalive, K.R. Tan, M. Terunuma, M.B. Munoz, M.N. Pangalos, J. Martínez-Hernández, M. Watanabe, S.J. Moss, R. Luján, C. Lüscher, P.A. Slesinger. Methamphetamine-evoked depression of GABA(B) receptor signaling in GABA neurons of the VTA. Neuron, 73 (2012), pp. 978-989

Paxinos and Watson, 2007. G. Paxinos, C. Watson. The Rat Brain in Stereotaxic Coordinates (sixth ed.), Academic Press (2007) Roberto et al., 2010. M. Roberto, M.T. Cruz, N.W. Gilpin, V. Sabino, P. Schweitzer, M. Bajo, P. Cottone, S.G. Madamba, D.G. Stouffer, E.P. Zorrilla, G.F. Koob, G.R. Siggins, L.H. Parsons. Corticotropin releasing

Neuropharmacology, Vol 102 (March 2016): pg. 197-206. DOI. This article is @ Elsevier and permission has been granted for this version to appear in e-Publications@Marquette. Elsevier does not grant permission for this article to be further copied/distributed or hosted elsewhere without the express permission from Elsevier. 
factor-induced amygdala gamma-aminobutyric acid release plays a key role in alcohol dependence. Biol. Psychiatry, 67 (2010), pp. 831-839

Roitman et al., 2008. M.F. Roitman, R.A. Wheeler, R.M. Wightman, R.M. Carelli. Real-time chemical responses in the nucleus accumbens differentiate rewarding and aversive stimuli. Nat. Neurosci., 11 (2008), pp. $1376-1377$

Sakaba and Neher, 2003. T. Sakaba, E. Neher. Direct modulation of synaptic vesicle priming by GABAB receptor activation at a glutamatergic synapse. Nature, 424 (2003), pp. 775-778

Sandner et al., 1996. G. Sandner, C. Bielajew, G. Fouriezos. Bicuculline microinjections into the ventral tegmental area of the rat: alteration of self-stimulation thresholds and of cytochrome oxidase activity in the brain. Behav. Brain Res., 79 (1996), pp. 145-151

Schmidt et al., 2006. H.D. Schmidt, S.M. Anderson, R.C. Pierce. Stimulation of D1-like or D2 dopamine receptors in the shell, but not the core, of the nucleus accumbens reinstates cocaine-seeking behaviour in the rat. Eur. J. Neurosci., 23 (2006), pp. 219-228

Shaham and Stewart, 1996. Y. Shaham, J. Stewart. Effects of opioid and dopamine receptor antagonists on relapse induced by stress and reexposure to heroin in rats. Psychopharmacology, 125 (1996), pp. 385391

Sinha et al., 1999. R. Sinha, D. Catapano, S. O'Malley. Stress-induced craving and stress response in cocaine dependent individuals.

Psychopharmacology, 142 (1999), pp. 343-351

Steffensen et al., 1998. S.C. Steffensen, A.L. Svingos, V.M. Pickel, S.J. Henriksen. Electrophysiological characterization of GABAergic neurons in the ventral tegmental area. J. Neurosci., 18 (1998), pp. 8003-8015

Tagliaferro and Morales, 2008. P. Tagliaferro, M. Morales. Synapses between corticotropin-releasing factor-containing axon terminals and dopaminergic neurons in the ventral tegmental area are predominantly glutamatergic. J. Comp. Neurol., 506 (2008), pp. 616-626

Takahashi et al., 1998. T. Takahashi, Y. Kajikawa, T. Tsujimoto. G-Proteincoupled modulation of presynaptic calcium currents and transmitter release by a GABAB receptor. J. Neurosci., 18 (1998), pp. 3138-3146

Tan et al., 2012. K.R. Tan, C. Yvon, M. Turiault, J.J. Mirzabekov, J. Doehner, G. Labouèbe, K. Deisseroth, K.M. Tye, C. Lüscher. GABA neurons of the VTA drive conditioned place aversion. Neuron, 73 (2012), pp. $1173-1183$

Tolu et al., 2013. S. Tolu, R. Eddine, F. Marti, V. David, M. Graupner, S. Pons, M. Baudonnat, M. Husson, M. Besson, C. Reperant, J. Zemdegs, C. Pagès, Y.A. Hay, B. Lambolez, J. Caboche, B. Gutkin, A.M. Gardier, J.P. Changeux, P. Faure, U. Maskos. Co-activation of VTA DA and GABA

Neuropharmacology, Vol 102 (March 2016): pg. 197-206. DOI. This article is @ Elsevier and permission has been granted for this version to appear in e-Publications@Marquette. Elsevier does not grant permission for this article to be further copied/distributed or hosted elsewhere without the express permission from Elsevier. 
neurons mediates nicotine reinforcement. Mol. Psychiatry, 18 (2013), pp. 382-393

Trojniar and Klejbor, 1999. W. Trojniar, I. Klejbor. Facilitatory effect of unilateral lesion of the ventral tegmental area on locomotor response to stimulation of the contralateral ventral tegmental area: involvement of GABAergic transmission. Brain Res., 842 (1999), pp. 419-430

Twining et al., 2015. R.C. Twining, D.S. Wheeler, A.L. Ebben, A.J. Jacobsen, M.A. Robble, J.R. Mantsch, R.A. Wheeler. Aversive stimuli drive drug seeking in a state of low dopamine tone. Biol. Psychiatry, 77 (2015), pp. 895-902

Ungless et al., 2003. M.A. Ungless, V. Singh, T.L. Crowder, R. Yaka, D. Ron, A. Bonci. Corticotropin-releasing factor requires CRF binding protein to potentiate NMDA receptors via CRF receptor 2 in dopamine neurons. Neuron, 39 (2003), pp. 401-407

Ungless et al., 2004. M.A. Ungless, P.J. Magill, J.P. Bolam. Uniform inhibition of dopamine neurons in the ventral tegmental area by aversive stimuli. Science, 303 (2004), pp. 2040-2042

Van Bockstaele and Pickel, 1995. E.J. Van Bockstaele, V.M. Pickel. GABAcontaining neurons in the ventral tegmental area project to the nucleus accumbens in rat brain. Brain Res., 682 (1995), pp. 215-221

van Zessen et al., 2012. R. van Zessen, J.L. Phillips, E.A. Budygin, G.D. Stuber. Activation of VTA GABA neurons disrupts reward consumption. Neuron, 73 (2012), pp. 1184-1194

Vranjkovic et al., 2014. O. Vranjkovic, P.J. Gasser, C.H. Gerndt, D.A. Baker, J.R. Mantsch. Stress-induced cocaine seeking requires a beta-2 adrenergic receptor-regulated pathway from the ventral bed nucleus of the stria terminalis that regulates CRF actions in the ventral tegmental area. J. Neurosci., 34 (2014), pp. 12504-12514

Wanat et al., 2008. M.J. Wanat, F.W. Hopf, G.D. Stuber, P.E. Phillips, A. Bonci. Corticotropin-releasing factor increases mouse ventral tegmental area dopamine neuron firing through a protein kinase Cdependent enhancement of Ih. J. Physiol., 586 (2008), pp. 2157-2170 Wanat et al., 2013. M.J. Wanat, A. Bonci, P.E. Phillips. CRF acts in the midbrain to attenuate accumbens dopamine release to rewards but not their predictors. Nat. Neurosci., 16 (2013), pp. 383-385

Wang et al., 2005. B. Wang, Y. Shaham, D. Zitzman, S. Azari, R.A. Wise, Z.B. You. Cocaine experience establishes control of midbrain glutamate and dopamine by corticotropin-releasing factor: a role in stress-induced relapse to drug seeking. J. Neurosci., 25 (2005), pp. 5389-5396

Wang et al., 2007. B. Wang, Z.B. You, K.C. Rice, R.A. Wise. Stress-induced relapse to cocaine seeking: roles for the $\operatorname{CRF}(2)$ receptor and CRFbinding protein in the ventral tegmental area of the rat.

Psychopharmacology, 193 (2007), pp. 283-294

Neuropharmacology, Vol 102 (March 2016): pg. 197-206. DOI. This article is @ Elsevier and permission has been granted for this version to appear in e-Publications@Marquette. Elsevier does not grant permission for this article to be further copied/distributed or hosted elsewhere without the express permission from Elsevier. 
NOT THE PUBLISHED VERSION; this is the author's final, peer-reviewed manuscript. The published version may be accessed by following the link in the citation at the bottom of the page.

Wang et al., 2012. B. Wang, Z.B. You, R.A. Wise. Heroin self-administration experience establishes control of ventral tegmental glutamate release by stress and environmental stimuli. Neuropsychopharmacology, 37 (2012), pp. 2863-2869

Waselus et al., 2005. M. Waselus, R.J. Valentino, E.J. Van Bockstaele. Ultrastructural evidence for a role of gamma-aminobutyric acid in mediating the effects of corticotropin-releasing factor on the rat dorsal raphe serotonin system. J. Comp. Neurol., 482 (2005), pp. 155-165

Wirtshafter and Sheppard, 2001. D. Wirtshafter, A.C. Sheppard. Localization of $\mathrm{GABA}(\mathrm{B})$ receptors in midbrain monoamine containing neurons in the rat. Brain Res. Bull., 56 (2001), pp. 1-5

Williams et al., 2014. C.L. Williams, W.C. Buchta, A.C. Riegel. CRF-R2 and the heterosynaptic regulation of VTA glutamate during reinstatement of cocaine seeking. J. Neurosci., 34 (2014), pp. 10402-10414

Wise and Morales, 2010. R.A. Wise, M. Morales. A ventral tegmental CRFglutamate-dopamine interaction in addiction. Brain Res., 1314 (2010), pp. 38-43

Xi and Stein, 1999. Z.X. Xi, E.A. Stein. Baclofen inhibits heroin selfadministration behavior and mesolimbic dopamine release.

J. Pharmacol. Exp. Ther., 290 (1999), pp. 1369-1374

Xi et al., 2004. Z.X. Xi, J. Gilbert, A.C. Campos, N. Kline, C.R. Ashby Jr., J.J. Hagan, C.A. Heidbreder, E.L. Gardner. Blockade of mesolimbic dopamine D3 receptors inhibits stress-induced reinstatement of cocaine-seeking in rats. Psychopharmacology, 176 (2004), pp. 57-65

Xia et al., 2011. Y. Xia, J.R. Driscoll, L. Wilbrecht, E.B. Margolis, H.L. Fields, G.O. Hjelmstad. Nucleus accumbens medium spiny neurons target non-dopaminergic neurons in the ventral tegmental area. J. Neurosci., 31 (2011), pp. 7811-7816

Yim and Mogenson, 1980. C.Y. Yim, G.J. Mogenson. Effect of picrotoxin and nipecotic acid on inhibitory response of dopaminergic neurons in the ventral tegmental area to stimulation of the nucleus accumbens. Brain Res., 199 (1980), pp. 466-473

Yoshida et al., 1994. M. Yoshida, H. Yokoo, T. Tanaka, H. Emoto, M. Tanaka. Opposite changes in the mesolimbic dopamine metabolism in the nerve terminal and cell body sites induced by locally infused baclofen in the rat. Brain Res., 636 (1994), pp. 111-114

Corresponding author. Department of Biomedical Sciences, Marquette University, USA.

Current address: Department of Integrative Physiology and Neuroscience, Washington State University Vancouver, USA.

Neuropharmacology, Vol 102 (March 2016): pg. 197-206. DOI. This article is @ Elsevier and permission has been granted for this version to appear in e-Publications@Marquette. Elsevier does not grant permission for this article to be further copied/distributed or hosted elsewhere without the express permission from Elsevier 
NOT THE PUBLISHED VERSION; this is the author's final, peer-reviewed manuscript. The published version may be accessed by following the link in the citation at the bottom of the page.

Neuropharmacology, Vol 102 (March 2016): pg. 197-206. DOI. This article is @ Elsevier and permission has been granted for this version to appear in e-Publications@Marquette. Elsevier does not grant permission for this article to be further copied/distributed or hosted elsewhere without the express permission from Elsevier. 